\title{
CORRESPONDENCE
}

\section{Dear Member,}

Scientists in liberated Europe need literature dealing with advances made in thought in Allied countries during the war. In particular, French scientists and philosophers require this literature as quickly as possible.

We have been asked to appeal to members of the British Institute of Philosophy to give to their French colleagues copies of PhILosophy from January r940 onwards: either complete sets or single numbers. All material sent to France would be fully used. Single copies would be microfilmed, and films and abstracts distributed; thus the greatest possible use could be made immediately of any periodicals.

Members who have sets or single copies of Philosophy to spare are asked to send them, at the earliest possible moment, to: The Association of Scientific Workers, Hanover House, 73 High Holborn, London, W.C.I.

Yours sincerely,

SYDNEY E. HOOPER,

Editor.

University Hall, 14, Gordon Square, London, W.C.I. March 1945.

DEAR SIR,

TO THE EdTroR of Philosophy

Since Dr. Laing quotes me in his article on Kant and Natural Science, perhaps I may be allowed a brief comment.

According to Kant, it is only by experience that we can discover the cause of a given effect or the effect of a given cause; and I pointed out that in this respect Kant agrees with Hume. On this Dr. Laing is good enough to inform me that it is the divergence from Hume-not the agreement-that will constitute Kant's answer to Hume. He fails to indicate that I have stated-as any commentator shouldboth the divergence and the agreement. Kant differs from Hume in holding that we have a priori knowledge of the causal principle itself. As I say in the next sentence: "Our a priori knowledge is confined to the statement that every event must have a cause." Thus Dr. Laing totally misrepresents my position even in the passage quoted-not to mention many others.

The reason behind this misrepresentation seems to lie in a curious prejudice which vitiates his argument thronghout. He maintains that in order to answer Hume Kant must show, not morely that the causal principle can be established a priori, but also that particular causal laws can be "deduced" from this principle and their truth "guaranteed" by it. He even attributes to Kant himself the claim that by establishing the a priori character of the principle of causation he has "automatically" established "the a priori character of empirical science"! Kant makes no claim to establish such a contradiction in terms: on the contrary he consistently repudiates it. What Kant claims is that ( $I$ ) the condition of the discovery of causal laws, and indeed the condition of our experience, is the general principle of causation; and (2) that this general principle can be established a priori by the Critical method. Kant may or may not be successful in justifying this answer to Hume, but there is no reasonable doubt that it is an answer. Yet Dr. Laing charges Kant with confusion because he does not give a quite different answer which would manifestly be false. Heaven knows there are enough difficulties in Kant's argument without adding to them artificially. If Dr. Laing wants to know why Kant did not give the kind of answer he demands, the only reply can be that Kant had too much sense.

14, Merton Street, Oxpord.

H. J. Paton. Nnember 9, 1944. 